\title{
Sigitas LŪŽYS
}

\section{DAUGIAKALBYSTE் LDK: REALIJOS, POLITIKA, ŽAIDIMAI}

Summary. The present article analyses the formation of multilingual society in medieval Lithuania. It aims specifically at investigating the origin of multilingualism in the Grand Duchy of Lithuania and its implications on the development of Lithuanian society, political and cultural peculiarity, linguistic diversity as well as the construction of ethnic identity. The Grand Duchy of Lithuania, a nationally and linguistically diverse, multireligious state, had to turn to multilingualism for internal and external communication. Firstly, multilingualism was encouraged by the aspiration to integrate the state of Lithuania into the Europe of those days in the cultural, economic and political sense (even in the pre-Christian period). The Grand Duke Gediminas in his letter, dated on 26 May 1323, addressed to the Franciscan monks, requested sending four brothers who knew Polish, Semigalii and Russian to Lithuania. Multilingualism flourished exceptionally in the internal communication of the Grand Duchy of Lithuania: at least six languages were used for the purposes of script and literature alone. The same number of languages was used in everyday communication among different ethnic groups. In the 16th century, the strengthening of linguistic policy manifestations enabled the formation of at least four cultural information dissemination codes that survived until the 19th century. All of them were based on signification of a different language as the aspect of cultural development. As the study revealed, the origin of Lithuanian multilingualism can be associated with both the geopolitical situation of the ancient Lithuania and internal political framework of a multinational state. Cultural, religious and political processes determined a specific situation of communication in the country which manifested itself by almost parallel use of several languages in societal life. Languages exerted impact upon the formation of four different cultural information dissemination codes, discerning the models of Lithuanian, Latin (Roman), Byelorussian and Polish or Sarmatian culture. Politicization of language performed in 1697, when on the basis of the law of Coequation (Coaequatio iurium) the Polish language was entrenched in state offices, indicated essential changes in the state language policy: the Polish language became one among the equal languages of the GDL. Still the multinationality and diversity of confessions were maintained in cultural communication, literature, religion and science. Multilingualism disappeared from the state offices to emerge in public paratheatre events and was firmly anchored in creativity for special occasions and sophisticated poetry where it was mainly expressed by multilingual greetings of sovereigns and the noble. Welcoming speeches (Gratulationes) form a specific genre of literature, directly related to traditions and habits of public life of the nobility. Welcoming speeches at large belong to the area of occasional creativity and illustrate linguistic literacy of the society and tendencies of imperial or political impact of those times. Apart from Lithuanian, such languages as Latin, Rusini (lot. Rutheni or old Byelorussian), Church Slavonic, Polish, Latvian, German, Italian, French were used; also other, rather exotic languages (in the case of GDL) such as Syrian, Hungarian, Finnish, Belgian, English, Scottish, Irish, Spanish, Czech can be found. Playings by languages and sometimes by alphabets were popular in a private setting as well. 
A number of such manifestations can be found in marginal printings (letters, notes of friendship, book proveniences and etc.). Although in the sunset of the Grand Duchy the societal multilingualism became narrower, it still existed owing to ethnic diversity and new emerging political tendencies in the country. Texts in several languages became a new form of communication. A colourful linguistic diversity of the Grand Duchy was evidenced by rich literary heritage, for instance, the macaronic (Latin macaronicum) style of poetry where poems written in Latin were intertwined with the words of national languages to reach a satirical or amusing effect. The conclusion is drawn in the study that Lithuanian multilingualism, closely related with societal multiculturalism and development of ethnic identity as well as religious tolerance of the ancient state, outlived the Grand Duchy of Lithuania: a new political situation in the 19th century failed to impose monolingualism both to private and partly to public life.

Keywords: multilingualism, GDL, writings, greetings (gratulationes), multilingualism, notes of friendship, "makaroniko" style of poetry.

Santrauka. Straipsnyje nagrinėjamas daugiakalbès valstybės formavimasis viduramžiu Lietuvoje. Siekiama išanalizuoti daugiakalbystès Lietuvos Didžiojoje Kunigaikštystejje ištakas bei jos sąsajas su Lietuvos visuomenès vystymusi, politiniu, kultūriniu savitumu, lingvistine ¿vairove ir etninio identiteto formavimusi. Lietuvos Didžioji Kunigaikštystè - daugiatautè, ¡vairiakalbè ir daugiareliginè valstybè vidinei ir išorinei komunikacijai buvo priversta vartoti daugiakalbystę. Visu pirma daugiakalbystę skatino siekis integruoti Lietuvos valstybę tiek kultūrine, ekonomine, tiek ir politine prasme i tuometinę Europa. Kunigaikščio Gedimino 1323 m. gegužès 26 d. laiške pranciškony ordinui i Lietuvą buvo kviečiami lenku, žemgaliu ir rusu kalbas mokantys vienuoliai. Itin plačiai daugiakalbystė LDK skleidėsi vidinejje komunikacijoje: vien rašto ir literatūros reikalams LDK vartotos mažiausiai šešios kalbos. Antra tiek kalbu vartota atskiru etniniu grupiu buitiniai komunikacijai. XVI a. sustiprejjusios kalbinès politikos apraiškos sąlygojo susiformavimą mažiausiai keturiems kultūriniu informacijos sklaidos kodu, išlikusiems iki pat XIX a. Jie visi rèmėsi skirtingos kalbos - kaip kultūrinès raidos veiksnio iškèlimu. Daugiakalbystè Lietuvos Didžiojoje Kunigaikštystejje formavosi ankstyvaisiais valstybès egzistavimo amžiais ir yra sietina tiek su geopolitine senosios Lietuvos situacija, tiek ir su vidine daugiatautès valstybès politine sąranga. Kultūriniai, religiniai ir politiniai procesai lèmè specifinę komunikavimo valstybejje situacija, pasireiškusią keleto kalbu beveik paraleliu vartojimu visuomenès gyvenime. Kalbos turejjo itakos ir keturiu skirtingu kultūriniu informacijos sklaidos kodu susiformavima, iškèlusi lietuviškaji, lotyniškaji (romèniškaji), gudiškaji ir lenkiškaji arba sarmatiškosios kultūros modelius. Kalbos politizavimas, ivykdytas 1697 m., kai remiantis Koekvacijos istatymu (Coaequatio iurium) valstybès kanceliarijoje isitvirtino lenku kalba, reiškè esminius pokyčius valstybès kalbinejje politikoje: pirma tarp lygiu LDK tapo lenku kalba. Tačiau valstybès daugiatautiškumas bei ivairiakonfesiškumas daugiakalbystę išlaikè kultūrinèje komunikacijoje, literatūroje, religijoje, moksle. Daugiakalbystè iš valstybès kanceliarijos pasitraukè i viešuosius parateatrinius renginius, isitvirtino proginejje kūryboje ir imantriojoje poezijoje, kur dažniausiai reiškèsi multilingvistiniais valdovu ir didiku sveikinimais. Sveikinimai (Gratulationes) - specifinis literatūros žanras, tiesiogiai susijęs su didiku rūmu viešojo gyvenimo tradicijomis ir papročiais. Sveikinimai daugeliu kalbu priklauso proginès kūrybos sričiai ir iliustruoja anuometini visuomenès lingvistini išprusimą bei imperinès arba politinès itakos tendencijas. Čia be lietuviu kalbos vartotos lotynu, rusènu, bažnytinè slavu, lenku, latviu, vokiečiu, italu, prancūzu kalbos, tačiau sutinkamos ir gana egzotišku (LDK atveju) kalbu: siru, vengru, suomiu, belgu, anglu, škotu, airiu, ispanu, čeku Žaidimai kalbomis, kartais ir abècèlèmis, plito ir privačioje aplinkoje. Nemaža tokiu apraišku pavyzdžiu randame marginalinèje raštijoje (laiškuose, draugystès irašuose, knygu proveniencijose ir t. t.). LDK saulèlydyje daugiakalbystè siaurejo, bet valstybès daugiatautiškumas ir atsiradusios naujos politinès slinktys lèmè jos tolesni gyvavimą mūsu krašte. Keliakalbiai tekstai virsta nauja komunikacijos forma, kurios esmè - makaroninis stilius, kai skirtingu kalbu fragmentai laisvai jungiami, nekeičiant tu kalbu ypatumu. Susiformavo net poezijos 
forma, paplitusi XVI-XVII a. Europoje, - makaronikas (lot. macaronicum), kai i lotynišką teksta iterpiami tautinès kalbos žodžiai arba jiems pridedamos kaitomos lotynišku žodžiu galūnès. Apibendrinant straipsnyje teigiama, kad Lietuvos daugiakalbystė, glaudžiai susijusi su visuomenès daugiakultūriškumu ir etninio identiteto formavimusi pergyveno ir pačią LDK: nauja politinè situacija XIX a. neistengè ne tik privačiam, bet iš dalies ir viešajam gyvenimui primesti vienkalbystès.

Pagrindinès sąvokos: daugiakalbystè, LDK, raštija, sveikinimai (gratulationes), draugu knygos, "makaroniko" poezijos stilius

Ivairiakalbė LDK raštija jau yra sulaukusi gana išsamiu tyrimu, analiziu bei vertinimu. Iš dabarties Lietuvos mokslininku šioje srityje daugiausiai yra nuveikę E. Ulčinaitè, S. Narbutas, D. Kuolys, nemažai kitu LDK kultūros ir literatūros tyrinètoju. Šiame straipsnyje dèmesys kreipiamas i kalbu ivairovę LDK viešajame ir privačiame gyvenime, i daugiakalbystès slinktis senosios Lietuvos kultūroje ir politikoje, taip pat jos modifikacijas asmeninejje erdvejje.

Lietuvos Didžioji Kunigaikštystè - daugiatautè, ivairiakalbè ir daugiareliginè valstybè - vidinei ir išorinei komunikacijai palaikyti buvo priversta priimti daugiakalbystę. Daugiakalbystès ištaku senojoje Lietuvoje reikètu ieškoti valstybès religineje tolerancijoje, akcentuotoje jau ankstyvojoje LDK gyvavimo stadijoje. Tai iliustruoja 1324 m. popiežiaus Jono XXII pasiuntiniu pranešimas apie ju prièmima Vilniuje. Prièmimo metu Lietuvos valdovas Gediminas pareiškęs, kad „krikščionims jis leidžiąs savo dievą garbinti pagal savo papročius, rusams pagal savo apeigas, lenkams pagal savo papročius, "o mes garbiname dievą pagal savo apeigas, ir visi turime viena dieva" (christianos facere deum suum colere secundum morem suum, ruthenos secundum ritum suum, polonos secundum morem suum et nos colimus deum secundum ritum nostrum, et omnes habemus unum deum) (Gedimino laiškai, 1966, p. 127, 129). Krikščioniu, rusu ir lenku lygiagretus ivardijimas rodo religinès priklausomybès nustatymą pagal apeigu kalbini požymi. Kalbu svarba religinėms apeigoms teigiama ir Lietuvos valdovo Gedimino 1323 m. gegužès 26 d. laiške pranciškony ordino vienuoliams, kuriame jis prašo atsiusti „mums šiais metais keturis brolius, mokančius lenku, žemgaliu ir rusu kalbas, tokius, kokie dabar yra ir kokie buvo [anksčiau]" (nobis hoc anno quatuor fratres scientes polonicum, semigallicum ac ruthenicum ordinetis, tales ut nunc sunt et fuerunt) (Gedimino laiškai, 1966, p. 55). Taip pat daugiakalbystę skatino siekis integruoti Lietuvos valstybę tiek kultūriniu, ekonominiu, tiek ir politiniu aspektu (dar ir ikikrikščioniškuoju laikotarpiu) i tuometinę Europa.

LDK geopolitinè padètis, jos „buvimas dvieju civilizaciju - bizantiškosios (stačiatikiškosios) ir lotyniškosios (katalikiškosios) - sąveiku" (Narbutas, 2006, p. 144) lauke bei gyventoju etninè ivairovè buvo esminis veiksnys, ilgai neleidęs isivyrauti vienai kalbai ir dominuoti vienai etninei grupei. Sudetingi ivairialypiai kultūriniai, religiniai ir politiniai procesai formavo pilietinę savimonę, siejamą labiau su valstybe nei etnosu ar kalba. Ši savimonè tapo telkiančia jèga ,priimant 
dvieju skirtingu civilizaciju, „apibūdinamu kaip Slavia Latina ar Romana ir Slavia Graeca ar Orthodoxa" (Narbutas, 2006, p. 149), itaką ir ją perkeičiant i "Lithuania Latina ir Lithuania Graeca" (Narbutas, 2006, p. 149). Apskritai reikia „i LDK kultūrą žvelgti kaip i tam tikrą ilgaamžę pamažu kitusią civilizaciniu santykiu sistema. Vienu metu joje mes regime stipresnę vienos kurios nors kalbos, tikejjimo ir pan. raišką; po kurio laiko dominavusius kultūros pavidalus joje keitè kitos formos, kuriu užuomazgos nerealizuotu galimybiu pavidalu glūdèjo ankstesnès sistemos gelmèse" (Narbutas, 2006, p. 144). Taigi, XV-XVI a. LDK buvo valstybè, kurioje dominavo kataliku religija, jos valdovai lietuviai dar suprato vietines baltu kalbas ar tarmes, bet rašè ir skaitè bažnytine slavu kalba, kalbejjo Rytu slavu tarmèmis, iš kuriu ilgainiui išsirutuliojo baltarusiu ir ukrainiečiu kalbos, ir save laikè senovès romènu palikuonimis. Centralizuojanti valstybès politika rèmèsi ne nacionalumu, bet pilietiškumu ir ekonominiu pragmatyvizmu. Ivairios tarnybos, privilegijos, benificijos buvo teikiamos ne pagal etninę ar kalbinę priklausomybę, bet už nuopelnus valstybei (šiuo aspektu traktuotina ir karaimu etninès grupès, dar Vytauto Didžiojo atkeltos i Lietuva, ivairiomis privilegijomis sukurta išskirtinè padètis, kurią nulèmè ju specifinè tarnyba valstybei - didžiojo kunigaikščio apsauga). Taip valdžios aparate - ar tai būtu Ponu taryba, kanceliarija, ar kariuomenè - jungèsi ivairios kalbiniu ir etniniu aspektu grupès arba asmenys, todèl kiekvienoje konkrečioje situacijoje buvo pasirenkama optimali komunikavimo priemonè. Ir toji priemonè neatlikdavo imperatyvo vaidmens už situacijos ribu. Lietuvis, užsiimantis raštvedyba senaja slavu kalba, arba rusènas, rašęs valdovo laiškus lotyniškai, ir toliau privačioje aplinkoje bendravo gimtaja kalba, liko lietuvis arba rusènas. Tai taikliai - tiesa, kalbèdamas apie tikejjimą - XVII a. pradžioje pastebejo poleminiu raštu autorius Meletijus Smotrickis traktate „Verificatia niewinności": "Jeigu yra tikruju rusènu (o ju turi ir privalo būti), juk ne iš karto išsigimsta kraujas to, kuris pakeičia tikejjimą: juk nebūna taip, kad jeigu kas iš rusènu tautos priima Romos tikejjimą, tuojau pat pagal prigimti jis tampa ispanas arba italas; rusènas nuo seno yra kilnus. Ne tikejjimas juk lemia, kad rusènas yra rusènas, lenkas - lenkas, lietuvis - lietuvis, o rusèniška, lenkiška ir lietuviška prigimtis... Tauriausiasis rusènu kraujas šiais laikais savo patikimumu yra vertingiausias Lietuvos Respublikos brangakmenis, atspaudas ir valdžia" (Короткий, 2006, p. 59). Susiformavusios Lietuvoje dualistinès rašto kultūros sistemos takoskyra buvo valstybès politiniai interesai, o ne personalijos: „vidaus reikalams dažniausiai tarnavo gudiškoji, užsienio - lotyniškoji ir vokiškoji produkcija" (Gudavičius, 1999, p. 444). Valdovo kanceliarijoje dirbo ¿vairiu tautybiu atstovai, nuo XV a. - ir lietuviai. „Lotyniškaja ar gudiškaja darbo sriti lèmè ne tautybè ar tikyba, bet išsimokslinimas: būta gudiškai rašančiu lietuviu (Jonas Kušleika) ar lotyniškai rašančiu gudu (Jonas Sapiega)" (Gudavičius, 1999, p. 445). Tiesa, lotyniškaji raštininką išlaikyti kainavo keturis penkis kartus brangiau už gudiškaji. Kitaip nei Vilniuje, "Kaune nemažas vaidmuo priklausė vokiečiu kalbai" (Gudavičius, 1999, p. 446). 
Rašto plitimas už valdovo kanceliarijos ribu, senosios Lietuvos raštijos palikimas atskleidžia itin marga LDK kalbinę ivairovę, verčiančia kalbèti ne tik apie „rusèniškaja, lenkiškaja, lietuviškaja, latviškaja, vokiškaja, judejiškaja, karaimiškaja, bet ir apie lotyniškaja LDK raštijos paveldo dali" (Narbutas, 2006, p. 144). Vien rašto ir literatūros reikalams LDK vartotos mažiausiai šešios kalbos. Antra tiek kalbu vartota jvairiu etniniu grupiu buitiniai komunikavimui.

XVI amžius LDK - didžiuju permainu amžius. Šiuo laikotarpiu imtos kelti visuomenès atsinaujinimo mintys, projektuoti valstybès raidos keliai. "Ankstesni rūpesti Lietuvos valstybe papildo rūpestis "lietuviu tauta", "Lietuvos Didžiosios Kunigaikštystès tauta" (Kuolys, 2000, p. 9). Nors "tauta" nebuvo tapatinama su kalba, bet sustiprèjusios kalbinès politikos apraiškos leido susiformuoti mažiausiai keturiems kultūriniams informacijos sklaidos kodams, išlikusiems iki pat XIX a. Visi jie rèmėsi skirtingos kalbos kaip kultūrinès raidos veiksnio iškèlimu. Tai lietuviškasis, lotyniškasis (romèniškasis), gudiškasis ir lenkiškasis arba sarmatiškosios kultūros modeliai. Lietuviškojo modelio apologetais laikytini Martynas Mažvydas, kaip esminę lietuviu tautos žymę nurodantis lietuviu kalbą, Žemaičiu vyskupas Merkelis Giedraitis ir Mikalojus Daukša, lietuviu kalba ivardijantys kaip „valstybès sarga", "pilietiškumo tèva"1. Lotyniškaji kultūros modeli siūlè lietuviu kilmès iš romėnu šalininkai Mykolas Lietuvis, Venclovas Jonas Agripa, Vilniaus vaitas Augustinas Rotundas, Antrojo Lietuvos Statuto vertimo i lotynu kalba 1576 m. pratarmèje rašęs: Lituanos ab Italis originem ducere, sermo agrestium, multum ad sermonem Italorum, tanto locorum et temporum intervallo, accedens, verisimile facit; nam nobiliores ex consuetudine, quam cum Polonis et Russis, ob commune imperium habent, Polono et Russo sermone, nativum permutarunt („Lietuviai yra kilę iš italu, kaip tai galima spèti iš liaudies kalbos, kuri daug kuo panaši i italu kalba, nepaisant to, kad jiedvi skiria taip didelis vietos ir laiko atstumas. Mat bajorai, begyvendami drauge su lenkais ir rusais bendroje valstybeje, vietoj gimtosios iprato vartoti lenku ir rusu kalba") (Rotundus, 2000, p. 296, 286).

Gudiškaji modeli gynė gudiškai surašyti trys Lietuvos Statutai, metraščiai, gausi polemine gudiškoji LDK raštija. Gudiškai rašytoje Trečiojo Statuto pratarmèje Lietuvos pakancleris Leonas Sapiega pabrèžè: "Ne kuria nors svetima, o sava kalba turime sudarytą teisyna" (Kuolys, 2000, p. 13). Ketvirtasis - lenkiškosios, sarmatiškosios kultūros - modelis daugiausia rèmèsi „kasdienio gyvenimo praktika, vertusia Lietuvos didikus ir bajorus XVI amžiuje vis dažniau tapatintis su kaimynine lenku kalba. Akivaizdi tokios praktikos išraiška - 1615 metais Jonušo Radvilo (1579-1620) laiške pusbroliui išsakytas apgailestavimas: „Nors lietuviu esu gimęs ir lietuviu teks man mirti, tačiau savo tèvynèje turime vartoti lenku kalba" (Kuolys, 2000, p. 13).

Taigi, kalba imama suvokti kaip itin svarbus pilietinę tautą formuojantis ir telkiantis veiksnys. Retorikos paveika priskiriama pačiai kalbai. Vilniaus akademijos teologijos profesorius, būsimasis jos rektorius, žemaitis Mykolas Ginkevičius

1 Žr. Kuolys, 2000, p. 9. 
(Michał Ginkiewicz, 1594-1663) tikino: „Kalba smogia kaip kardas, degina kaip ugnis, skaldo kaip kirvis, smaugia kaip virvè, persmeigia kaip kuolas. Pikta kalba - dažnas savižudybès inagis: Sunkiai kas nusižudytu kardu, bet nuo savos kalbos miršta tiek sielu, kiek žiemos miške [prikritusiu] lapu. Kardas, perskrodęs kūna, negali perverti sielos, tačiau kalba pirmiausiai paverčia lavonu siela, o tik paskui - kūna" (Kuolys, 2009, p. 30). Kalbos politizavimo rezultatai pasirodè 1697 m., kai ivyko esminis valstybès kalbos politikos pokytis: vadovaujantis Koekvacijos istatymu (Coaequatio iurium), valstybès kanceliarijoje isitvirtino lenku kalba. Tačiau LDK daugiatautiškumas ir jvairiakonfesiškumas daugiakalbystę išlaikè kultūrinejje komunikacijoje, literatūroje, religijoje, moksle. Tik atspalvis jau buvo kitas. XVI-XVII a. Lietuvos Didžiojoje Kunigaikštystėje nemažai kūriniu buvo išleista lygiagrečiai dviem kalbomis: lotynu ir lenku, lotynu ir vokiečiu, lotynu ir gudu, šiek tiek lotynu ir lietuviu kalbomis. Bet, žinoma, ima dominuoti lenku kalba, kuri jau politiškai žymèta, turi daugiau konkrečiu adresatu. Pavyzdžiui, Elijaus Piligrimovijaus (Elias Pielgrzymowski, Piligrimovius, ?-1604) lotynu ir lenku kalbomis parašytos poemos "Philopatris ad Senatum populumque Lituanum" ("Tèvynès mylètojas Lietuvos senatui ir tautai”, 1597) lotyniškasis ir lenkiškasis tekstai skiriasi. „Lotyniškasis tekstas, paremtas antikinès literatūros frazeologija, mitu aliuzijomis, yra abstraktesnis, universalesnis, intelektualesnis. Lenkiškajame tekste antikinès sąvokos keičiamos konkretesniais, liaudiškesniais posakiais, pasakojimas tampa intymesnis, emocionalesnis. Akivaizdu, jog jie adresuoti skirtingu visuomenès sluoksniu žmonėms: lotyniškasis tekstas - išsilavinusiems didikams, dvasininkams, akademinès bendruomenès atstovams, o lenkiškasis bajorams, menkesnio išsilavinimo ar žemesnès kilmės žmonèms, apie kuriuos

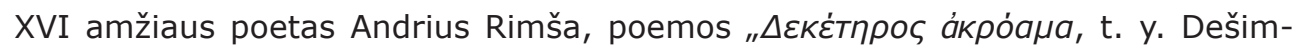
tmetis pasakojimas" (Vilnius, 1595) autorius, rašè: „dèl savo nekilmingumo, visiems prastiems žmonèms, kaip tik tokiems, kurie geriau kardu silogizmuoja, ietim argumentuoja, čimburu paremia, negu lotynu kalba diskutuoti yra išmokę, eilèmis lenku kalba ši „Dešimtmeti pasakojima..." parašiau” (Ulčinaitè, 2006, p. 69-70).

Taip daugiakalbystè LDK traukèsi iš valstybès kanceliarijos i viešuosius parateatrinius renginius, isitvirtino proginèje kūryboje ir imantriojoje poezijoje, dažniausiai kaip multilingvistiniai valdovy ir didiku sveikinimai. Sveikinimu (gratulationes) žanrą LDK itvirtino ir išpuoselejo jèzuitai. Kalbos čia tarsi atskiri veikèjai, visuotinio viešojo gyvenimo teatro dalyviai varžosi, kuri ispūdingiau pasveikins i sostinę atvykusi valdovą arba svarbu besilankanti didika. Aišku, pagrindinis vaidmuo tenka sakytineje ir rašytinejje kultūroje vyravusiai lotynu kalbai, dažnos senosios akademinès graiku ir hebraju kalbos, taip pat Lietuvos Didžiojoje Kunigaikštystejje vartotos rusènu, bažnytinè slavu, lenku, latviu, vokiečiu kalbos, tačiau pasitaiko ir gana egzotišku (LDK atveju) - siru, vengru, suomiu, belgu, anglu, škotu, airiu, italu, ispanu, čeku kalbu. Žinoma, Lietuvos didžiuju kunigaikščiu rūmuose valdovai bei kiti svečiai buvo sveikinami ir lietuviu kalba. 
1589 m. i Vilniu atvykęs Lietuvos didysis kunigaikštis ir Lenkijos karalius Zigmantas Vaza Vilniaus universiteto studentu buvo pagerbtas sveikinimu rinkiniu "Sveikinimai šviesiausiajam ir galingiausiajam valdovui Zigmantui III" (Gratulationes Serenissimo ac Potentissimo Principi Sigismundo III) bei priedu "Ivairios kalbos" (Linguae variae), kuriame pateikti sveikinimai italu, ispanu, prancūzu, vokiečiu, anglu, lenku, lietuviu kalbomis. Čia idètas pirmasis lietuviškas hegzametras ir vienas iš pirmuju hegzametru nacionaline kalba Europos literatūroje "Pakvietimas Viešpaties Karaliaus" (Kalbu varžybos, 2010, p. 214).

Tais pačiais metais išleistas dar vienas Zigmantui Vazai skirtas Vilniaus universiteto studentu sveikinimu rinkinys. Jo autoriai - Mikalojus Pacas, Jonas Komparskis, Jurgis Tiškevičius ir kt. Dauguma sveikinimu - lotyniški, tik Valentinas Tomas Suomis pasveikino suomiškai, o Petras Montanas Švedas - švediškai (karaliui gimtosiomis kalbomis) (Kalbu varžybos, 2010, p. 224, 228).

1648 m. pavasari atvykęs i Vilniu, Lenkijos karalius ir Lietuvos didysis kunigaikštis Vladislovas Vaza buvo pagerbtas literatūriniu sveikinimu rinkiniu "Lukiškiu pavasaris" (Ver Lukiskanum..., Vilnae, 1648). Rinkinys papildytas priedu „Kalbu varžybos" (Certamen linguarum), kuriame tekstai pateikiami net 19 kalbu: prancūzu, hebraju, graiku, lotynu, siru, italu, ispanu, vokiečiu, belgu, bažnytine slavu, rusènu, latviu, lenku, vengru, anglu, škotu, airiu, čeku, lietuviu. "Tai didžiausias ¿vairiakalbiu tekstu leidinys Lietuvos Didžiojoje Kunigaikštystèje" (Kalbu..., 2010, p. 54).

Paskutinis tokio pobūdžio leidinys skirtas Slupovo grafui, Lenkijos Karalystès sekretoriui, Varmijos ir Sembos vyskupui Kristupui Jonui Šembekui (1680-1740), apsilankiusiam Vilniuje 1729 m. Vilniaus jèzuitu kolegijos ir universiteto bendruomenè sutiko vyskupa literatūriniu sveikinimu rinkiniu „Kalbu visetas didžiajam Palemono žemès ir miesto svečiui" (Universitas linguarum magno Palaemonii orbis et urbis hospiti..., Vilnae, 1729). Rinkinio eilèraščiai parašyti hebraju, graiku, lotynu, slavu, prancūzu, lenku, vokiečiu, lietuviu, latviu kalbomis. „tvairiomis kalbomis sveikindami valdovus ir didikus, Vilniaus jèzuitu kolegijos ir universiteto studentai bei profesoriai siekè pademonstruoti savo erudicija, kalbu mokèjima, poetikos ir retorikos formu ivaldymą bei ju raiškos galimybes" (Kalbu..., 2010, p. 214).

Žaidimai kalbomis, kartais ir abècèlèmis, plito ir privačioje aplinkoje. Nemažai tokiu apraišku pavyzdžiu randame marginaliojoje raštijoje (laiškuose, draugystès irašuose, knygu proveniencijose ir t. t.). Ši kuriančiojo daugiakalbio žmogaus nuostata skverbėsi ir i privačia aplinką. Rašoma ivairiomis progomis ir ivairiomis kalbomis, kuriamos rašymo situacijos, ipareigodavusios rašyti. Atsiranda nuorašu ir irašu rinkiniu ${ }^{2}$, svečiu ir draugu knygu. Manoma, kad ši mada Lietuvą pasiekè greičiausiai per Lenkija. Šiuo metu Lenkijoje, Krokuvos Čartoryskiu bibliotekoje, saugoma viena iš tokiu knygu, tiksliau, rankraštis (Rkp, 1403) „Pamiętnik przyjaciół Andrzeja Lubienieckiego", rašytas 1617-1619 m. Rakove. Andriejus Lubieneckis (apie 1551-1623), arijonu pastorius ir rašytojas, pagarsèjęs diskusijomis

2 Žr. Bystroń, 1994, p. 417. 
Švč. Trejybès tema, turèjo albuma, i kuri artimi jo draugai ir pasekejjai, ne tik iš Lenkijos ir ne tik lenkai, irašydavo ivairiu Biblijos citatu ir, žinoma, pasirašydavo. Albumas itin idomus daugiakalbiškumu. Łrašu esama šiomis kalbomis: lotynu, lenku, sen. graiku, siru, hebraju, arabu, vengru, italu, vokiečiu, prancūzu, olandu, armènu, ispanu, lietuviu, rusu, persu, turku, švedu, žemaičiu, bulgaru, slovaku, čeku, chaldejju. Lietuviškai irašę yra ir lietuviai, ir lenkai. Taip tikriausiai buvo pataikaujama šeimininko norui turèti irašu kuo daugiau kalbu. Be to, nereti keliakalbiai irašai. Vien lietuviškai $1617 \mathrm{~m}$. spalio 12 dieną isirašè svečias iš Lietuvos Andrius Rakiška: Jonas szwentas pirmoia gromatoia Atskirime trzetzeme Rasza tuw budu Tataij esti przijsakimas pon diewa $j$ dant mes tiketubime jng warda sunaus jo jezusa christusa, ir miłetubime wienas antra kaip mumus dawe przjsakima Jo milistaij ponu Andrzeiu liubenickamuij pagal krawia jezusa christusa broliu mielawsiam Andrzeius Rakiska raka sawa Raszyta rakawe metuose 1617 menesia pazdzernika 12 dwilikuia dienu (Rkp, 1403, p. 68). Kitu metu gegužès 24 diena, lankydamasis Rakove, isiraše žemaitis Jonas Okielevičius. Jo irašas yra lotynu ir lietuviu kalbomis: Da operam ut vivens laudabilis, defunctus beatus existimeris. Apocaly. 3. fr 21. Litvanice Kursay piargałes, duasiu iamuy sedeti su manimi ant kresła mano, kayp ir asz piargałeiau, ir sedziu su Tewu mano ant kresła io. Pio \& Intigerrimo atq Clarissimo Viro, Dno Andreae Lubieniecio a Lubieniec, Ministro verbi Dei fideliss amoris \& honoris ergo, scripsit haec Racoviae 24 Maij Ao 1618, Joannes Okielewicz Minister in Samogitia (Rkp, 1403, p. 117). Tu pačiu 1618 metu gegužès 27 diena, viešèdamas Rakove, isirašo ir Kèdainiu miestietis Stanislovas Burnevičius. Jis taip pat Šv. Rašto citata pateikia lietuviškai, o žinias apie save rašo lenkiškai: Joan $6 \mathrm{fr} 40$. Litvan. Toi ira walia téwo ano kursaij mane pasiunte, idant kiekwienas kursaij règi sunu Ir tiki ingh I turetu ziwata amzina, o asz $g$ hi pribudisiu paskutinioij dienoij. Zacniemu ij Poboznemu miężowi Jego Msci Panu Andrzeiowi Lubienieckiemu, ku wieczneij pamięci napisał w Rakowie 27 Maij Roku 1618 Stanisław Burniewicz. Obijwatel miasta Kieydanskiego w ziemi Zmuijdtskieij (Rkp, 1403, p. 177).

Taigi, žvelgiant ne i viso rinkinio kalbu ivairovę, bet i pavienius irašus, akivaizdi irašu dvikalbystè. Greta lotynu kalbos vis didesnę svarbą igaunanti lenku kalba smulkiojoje marginaliojoje raštijoje iš pradžiu buvo pasitelkiama papildomai informacijai pateikti. Pavyzdžiui, nuosavybès irašai knygose (proveniencijos): Pan Bog roskazał nam bycz dobrey misli. Ego sum possesor huius libri Stanislaus Vołotkowicz Anno Domini 1634. Arba: Księga ta kupiona za złotych dwa posessor huius libri Stephanus Bogdanowicz Presbyter to iest kapłan. Arba: Fr Thomae Prasneri. Pro loco Cretingensi ir ten papildomas irašas: z Biblioteki Kretyngowskiey. Esama provenienciju, kuriose lotynu kalba rašomos eilès, o lenku - proza: Hic Liber meus Testis est Deus qui Illum querit Hic Nomen Erit Petrus Natus Mackiewicz vocatus; z Ksiąg Mackiewicza. Ilgainiui mikrotekstuose isivyrauja praktika pateikti vertimą. Dažniausiai tai neilgos sentencijos ar Biblijos frazès, pvz.: psal: 145 Nolite Confidere in principibus in filijs hominũ in quibو non est salus Nie 
ufaicie $w$ Xiązetach $w$ sinach ludzkich $w$ ktorych niemasz nadziei. Esama ir ištisu eilèraščiu vertimu, pvz., Georgo Mejerio (Georg Meier, 1502-1574) homiliju tomelyje, išleistame 1563 m. Vitenberge, ranka irašytas ištisas dvikalbis Renesanso poeto, Neapolio patricijaus Jokūbo Sanazaro (Jacopo Sannazaro, 1456-1530) eilèraštis apie Venecija ${ }^{3}$.

Greta vertimu aptinkame dar vieną kalbiniu žaidimu atmainą, tam tikrą poesis artificiosa preliudija, t. y. žaidimus abècèlèmis. Štai Jono Andžeikevičiaus (1605-1674) tomelyje "Ziarno gorczyczne" (Vilnius, 1673, p. 166, 167) užtinkame teksto transliteracijos bandymu: Dомине нонь сумь Dигнус. Domine non sum dignus ut intres Sub tectum meum; sed tantum... Kartais tokio žaidimo abècèlèmis griebiasi knygos savininkas, siekdamas "sublizgèti" savo mokytumu, erudicija, pvz., Jonas Petrovskis parodo savo graiku kalbos žinias: Joañes Piotrowskij

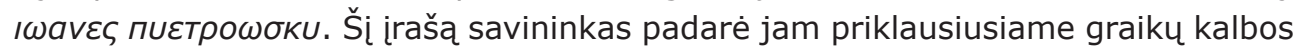
vadovèlyje (Clénard, Nicolas. Institutiones absolutissimae in Graecam linguam. Leipzig, 1576).

Abècèliu, kalbu maišymosi galima pastebèti ir paprasčiausiuose plunksnos bandymuose, pvz., Proba Jesus et Maria bona Compania. Dvikalbiai tekstai virsta nauja komunikacijos forma, kurios esmè - makaroninis stilius, kai jvairiu kalbu fragmentai laisvai jungiami, nekeičiant tu kalbu ypatumu. Atsirado net tam tikra poezijos forma, paplitusi XVI-XVII a. Europoje, - makaronikas (lot. macaronicum), kai i lotynišką tekstą iterpiami tautinès kalbos žodžiai arba jiems pridedamos kaitomos lotynišku žodžiu galūnès. Tarp makaronišku tekstu, nors ir retai, pasitaiko lenkišku-lietuvišku, pvz., Według wzyczaju kośćioła Swiętego Ing eyt in Stona S Moterystes Michołas Ziogas iz Pryszmanciu, Su Elżbietha Katenie naszłe iz Kretyngos. Tačiau dažniausi lotyniški-lenkiški tekstai, pvz., Tytuvėnu bernardinu vienuolyno gvardijono Gabrieliaus Radvanskio laiškas: Adrĩ Rñde Pater Minister Provincialis Pater Colendissime Superior Dignissime. Listy przysłane jak z Datnowa, tak z kowna od O. Diffinitora adsyłam. Samego W Dobrodzieja præzencj avidissime w dobrym zdrowiu czekamy. Interim Dasie oycowskiey mię oddawszy Pisiękę Adñ Rndæ Ptt̃is suæ Clendissimi Indigng Exorator Fr Gabriel Radwański Gvard C. Makaroniškasis stilius privačioje aplinkoje itin išplito XVIII a.

3 Viderat adriacis Venetam Neptunus in oris Stare Urbem, et toti ponere jura mari.

Non mihi Tarpeias quantumvis Jupiter arces

Objice, et illa tui moenia Martis ajit:

Si pelago Tiberim, urbem aspice utramque Illam Homines dices, hanc posuisse Deos. Postrzeg Neptun Weneckie miasto na odna... Adryackiey co trzyma morze iak na wade Niepokazuy mi teraz, rzekł, Jowiszu Góry Na których karku pyszne stoią Rzymu mury Wiem, zwazywszy swóy Tyber z mymi ... Bóg panie Tam założyli Ludzie tu sami Bogowie. 
Makaroniką kaip literatūrinę formą Lietuvoje sèkmingai idiegè dar XVI a. pabaigoje poetas ir teisininkas Petras Roizijus. Išlikęs jo lotyniškas hegzametras su lenkiškais intarpais (prie lenkišku žodžiu pridètos lotyniškos galūnès) "Apie kelionę per Lietuva", "parašytas tikriausiai apie 1560 m., yra ankstyviausias žinomas makaronikas Lietuvoje" (Patiejūnienè, 1992, p. 219). Aiškiai matyti, jog gramatinès makaroniko formos, leksika, sutirštintos pasakojimo spalvos turi sukelti komiška efekta, pralinksminti skaitytoją ar klausytoja, paskatinti ji isitraukti i panašu žaidima, skirta, be abejo, intelektualiai publikai ${ }^{4}$.

Dar vienas P. Roizijaus makaronikas vadinasi "Sapfinès eilès girtuokliams" (In bibulos saphicum) (Petri Royzii..., 1900, p. 263). Čia su jam būdinga ironija ir šmaikštumu poetas juokiasi iš sarmatu polinkio girtuokliauti, vadindamas tai „senu ir paplitusiu papročiu" ${ }^{5}$. XVII-XVIII a. Lenkijoje makaroninè kūryba (lenkiški

4 Viderat adriacis Venetam Neptunus in oris

Stare Urbem, et toti ponere jura mari.

Non mihi Tarpeias quantumvis Jupiter arces

Objice, et illa tui moenia Martis ajit:

Si pelago Tiberim, urbem aspice utramque

Illam Homines dices, hanc posuisse Deos.

Postrzeg Neptun Weneckie miasto na odna...

Adryackiey co trzyma morze iak na wade

Niepokazuy mi teraz, rzekł, Jowiszu Góry

Na których karku pyszne stoią Rzymu mury

Wiem, zwazywszy swóy Tyber z mymi ... Bóg panie

Tam założyli Ludzie tu sami Bogowie.

„Apie kelionę per Lietuva”"

Jeigu koks gościus jeździos kada nors po lietuviškus kaimus,

Ar jis per Vilniu keliautu, ar gautu iš ten wyjeździoti,

Tas su savim niechaj ir rżano chlebo, ir biało

Vežasi ratuos; baisus be vežimo išvykti jest błądas.

Viską gabentis tau teks, ko kelionej tokioj potrzeboja,

Druskos taip pat, nes antraip beskones potrawas jadosi,

Niech tavo bębenas bus wyborno alaus pilnutèlis, -

Piąteke raugto paimk, albo to, kuri Sobota siunčia.

Miódo taip pat tenetruks, ar młodo, ar staro, żołądkui

Kurs naudingesnis, nors głowai sunkus, ir mielas pijaniems.

Vyną jei mégsti, ir jo būtinai isidèk i vežimą:

Ištisą drogą ieškok - nienajdziesz parduodamo niekur,

Ar ladajako, nors pats už kiekvieną kroplą mažiausią

Būtum gotowas pažert po skambu szelągą; o jeigu

Savo szklanicos nebus, tai iš kuflo dzabankowo plugawo

Gerti tau teks ar galbūt iš kokios okopciałos konewkos,

Smerdai mużykai kurią neseniai nuo burnos atitraukè.

Czapka savaja dažnai naudosiesi vietoj lichtarzo,

Nożą i ścianą šiam tikslui bedžiosi ar dési i stalo

Viduri sztuką kažkokia, iš rżano chlebo padirbta,

Kaip kai kurie yra pratę čionai, išgremžtą w pośrodku.

Jei neturési pościelès, tai słoma pabus tau už guoli, 
tekstai su lotyniškais intarpais) buvo labai populiari ir poezijoje, ir prozoje, ypač retorinejje. Kitakalbę LDK literatūrą taip pat veikè ši tendencija, o lietuviškają raštija - dar ir stiprèjanti lenku kalbos itaka visose kultūrinio gyvenimo srityse. Daugelio XVII a. II pusès - XVIII a. LDK lietuviškai rašiusiu autoriu kūryboje žymūs makaronizmo pèdsaku, ju aptinkama ir XIX a. pradžios poezijoje.

Apibendrinant galima teigti, kad daugiakalbystès ištakos Lietuvoje sietinos su LDK etnine ivairove ir senosios valstybès religine tolerancija. Centralizuojanti valstybès politika išmintingai rèmèsi ne nacionalumu, bet pilietiškumu ir ekonominiu pragmatyvizmu. Kalba nebuvo paversta policiniu imperatyvu, bet visada išliko tik komunikavimo priemonè. Ir ta priemonè neatlikdavo imperatyvo vaidmens už situacijos ribu. Raštijos palikimas patvirtina itin marga LDK kalbu ivairovę: turime LDK raštijos paveldo rusènu, lenku, lietuviu, latviu, vokiečiu, judejju, karaimu, lotynu. Ilgainiui stiprejjančios atskiru kalbu pozicijos leido susiformuoti mažiausiai keturiems kultūriniams informacijos sklaidos kodams, išlikusiems iki pat XIX a. Tai lietuviškasis, lotyniškasis (romėniškasis), gudiškasis ir lenkiškasis arba sarmatiškosios kultūros modeliai. Priemus Koekvacijos istatyma, valstybès kanceliarijoje isitvirtino lenku kalba. Tačiau daugiakalbystè išliko kultūrinèje komunikacijoje, literatūroje, religijoje, moksle, perèjo i viešuosius parateatrinius renginius, isitvirtino proginèje kūryboje ir imantriojoje poezijoje. Žaidimai kalbomis, kartais ir abècèlèmis, plito ir privačioje aplinkoje. Nemažai tokiu apraišku pavyzdžiu randame marginaliojoje raštijoje (laiškuose, draugystès irašuose, knygu proveniencijose ir t. t.). Atsirado net tam tikra poezijos forma - makaronikas (lot. macaronicum), kai i lotynišką tekstą iterpiami tautinès kalbos žodžiai arba jiems pridedamos kaitomos lotynišku žodžiu galūnès. Daugiakalbystẻ pergyveno ir pačią LDK: nauja politinè situacija XIX a. neistengè primesti vienkalbystès ne tik privačiam, bet iš dalies ir viešajam gyvenimui.

\section{Literatūra}

Bystroń, J. S. (1994). Dzieje obyczajów w dawnej Polsce, wiek XVI-XVIII, t. 1. Warszawa: Państwowy Instytut Wydawniczy.

Gedimino laiškai. (1966). Parengè V. Pašuta ir I. Štal. Vilnius: Mintis.

Gudavičius, E. (1999). Lietuvos istorija nuo seniausiu laiku iki 1569 metu. Vilnius: Lietuvos rašytoju sajungos leidykla.

Ława kieta tau leis pavargusi kūną ištiesti.

Jeigu spustels speigai, paguldys tave ciemnoje izboj, -

Netgi dieną aplink vien tik nakti, vien dymus regési.

Tarpu krowu kai knarksi ramus bei švelniuju cielątku,

Jokio zegaro nereiks: žindukliai prosiętai su močia

Tuoj miegus išblaškys, nors drūnytum tarsi kamienius.

Kiaurą nakti kramtys tau ciałą pluskwa śmierdząca.

Vertè Eglè Patiejūnienè 
Kalbu varžybos. Lietuvos Didžiosios Kunigaikštystès valdovu ir didiku sveikinimai. (2010). Parengè, iš lotynu k. išvertè, ivadą ir komentarus paraše Eugenija Ulčinaitè. Vilnius: Nacionalinis muziejus Lietuvos Didžiosios Kunigaikštystès valdovu rūmai.

Kuolys, D. (2000). Visuomenès raidos projekcijos XVI amžiaus Lietuvos Didžiosios Kunigaikštijos raštijoje. Šešioliktojo amžiaus raštija (Senoji Lietuvos literatūra, kn. 5). Vilnius: Pradai.

Kuolys, D. (2009). Res Lituana. Kunigaikštystės bendrija. Pirmoji knyga: Respublikos steigimas. Vilnius: Lietuviu literatūros ir tautosakos institutas.

Narbutas, S. (2006). Latinitas LDK raštijos raidoje. Senoji Lietuvos literatūra, kn. 21. Vilnius: Lietuviu literatūros ir tautosakos institutas.

Patiejūnienè, E. (1992). P. Roizijaus makaronikas „Apie kelionę per Lietuva”. Senosios literatūros žanrai (Senoji Lietuvos literatūra, kn. 1). Vilnius: Mokslo ir enciklopediju leidykla.

Petri Royzii Maurei Alcagnicensis carmina (1900). Edidt, praefatione de vita operibusque Royzii commentariisque instruxit Bronislavus Kruczkiewicz, t. 2. Cracoviae: Typis Universitatis Jagellonicae.

Rotundus, A. (2000). Epitome Principum Lituaniae. Šešioliktojo amžiaus raštija (Senoji Lietuvos literatūra, kn. 5). Vilnius: Pradai.

Ulčinaitè, E. (2006). Lietuvos Didžiosios Kunigaikštystės XVI-XVII amžiaus dvikalbis tekstas: adresatas ir kalbinè raiška. Senoji Lietuvos literatūra, kn. 21. Vilnius: Lietuviu literatūros ir tautosakos institutas.

Короткий, В. (2006). Термин „Речь Посполитая Литовская в полемической литературе Великого княжества Литовского XVI-XVII веков". Senoji Lietuvos literatūra, kn. 21. Vilnius: Lietuviu literatūros ir tautosakos institutas.

\section{Sigitas LŪŽYS Lecturer of Latin Language}

Fields of scientific interests: classical languages, ancient books, Latin culture and literature of the Grand Duchy of Lithuania

Institute of Foreign Languages, Vytautas Magnus University

K. Donelaičio str. 52, LT-44244 Kaunas, Lithuania s.luzys@uki.vdu.It

\section{Sigitas LŪŽYS Lotynu kalbos lektorius}

Moksliniu interesy sritys: senosios kalbos, senoji knyga, LDK lotyniškoji kultūra ir literatūra

Vytauto Didžiojo universitetas, Užsienio kalbu institutas

K. Donelaičio g. 52, LT-44244 Kaunas, Lietuva

s.luzys@uki.vdu.It 